\title{
Late Pleistocene palaeoproductivity patterns during the last climatic cycle in the Guyana Basin as revealed by calcareous nannoplankton
}

\author{
G.-E. López-Otálvaro ${ }^{1}$, J. A. Flores ${ }^{1}$, F. J. Sierro ${ }^{1}$, I. Cacho ${ }^{2}$, J.-O. Grimalt ${ }^{3}$, E. Michel ${ }^{4}$, E. Cortijo ${ }^{4}$, and L. Labeyrie ${ }^{4}$ \\ ${ }^{1}$ Dept. of Geology, Univ. of Salamanca, Plaza de la Merced s/n, 37008 Salamanca, Spain \\ ${ }^{2}$ Dept. of Stratigraphy, Palaeontology and Marine Geosciences, Univ. of Barcelona, Martí i Franquès, 08028 Barcelona, Spain \\ ${ }^{3}$ Dept. of Environmental Chemistry, Institute of Chemical and Environmental Research (IIQAB-CSIC), Jordi Girona 18, \\ 08034 Barcelona, Spain \\ ${ }^{4}$ Laboratoire des Sciences du Climat et de l'Environnement, IPSL, Laboratoire Mixte, CEA-CNRS-UVSQ, Parc du CNRS, \\ 91198 Gif-sur-Yvette Cedex, France
}

Received: 6 February 2008 - Published in eEarth Discuss.: 17 March 2008

Revised: 5 March 2009 - Accepted: 5 March 2009 - Published: 2 April 2009

\begin{abstract}
Variations in the assemblage and abundance of coccoliths reveal changes in oceanic and atmospheric dynamics in the Guyana Basin over the last climatic cycle, mainly linked to latitudinal variations in the ITCZ (Intertropical Convergence Zone). Records of the $\mathrm{N}$ ratio (a palaeoproductivity index of coccolithophores) allowed us to monitor nutri-thermocline fluctuations. Nannofossil accumulation rates (NAR) vary closely with the $\mathrm{N}$ ratio, indicating a strong correlation between these two palaeoproductivity proxies. Decreases in the $\mathrm{N}$ ratio and NAR values suggest lower palaeoproductivity during glacial substages, indicating a deep nutri-thermocline (deep stratification of the mixed layer) as a consequence of the piling up of warm water dragged by the NEC. This setting was favoured by the southern shift of the ITCZ and Trade winds which blew perpendicular to the Guyana coast. By contrast, increases in the N ratio and NAR values revealed higher palaeoproductivity during interglacial substages, suggesting a shoaling of the nutrithermocline. This scenario is favoured by a northward displacement of the ITCZ with the southeast Trade winds blowing alongshore. Additionally, palaeoproductivity changes during substages of Marine Isotope Stage (MIS) 6-5 are of much higher amplitude than those recorded in substages of MIS 4-2 and the early Holocene. Similarities between the palaeoproductivity and the $65^{\circ} \mathrm{N}$ summer insolation records, suggest a link between the depth of nutri-thermocline, the latitudinal migration of the ITCZ and ice-sheet changes in the Northern Hemisphere.
\end{abstract}

\section{Introduction and background}

Coccolithophorids are photosynthetic planktonic algae living in the photic layer of the ocean (Hibberd, 1976; Brand, 1994; Young, 1994; Winter et al., 1994). They play a significant role in carbonate precipitation (Siesser and Winter, 1994; Steinmetz, 1994). The temporal and spatial distribution of coccolithophores may respond to major environmental factors in the upper oceanic layer such as temperature, nutrients, the trophic regime and sunlight levels (Brand, 1994; Young, 1994). For example, Florisphaera profunda, a phytoplankton species, thrives in the lower photic layer (Okada and Honjo, 1973; Okada and McIntyre, 1977) at times of high nutrient concentrations, pointing to a deep nutricline (e.g., Molfino and McIntyre, 1990a, b; de Menocal, 1995; Beaufort et al., 1997; Wells and Okada, 1997; Flores et al., 1999, 2000; Kinkel et al., 2000; Beaufort et al., 2001; Gibbs et al., 2004). The relationship between dwellers from the upper photic zone and those from the lower photic zone has been used to monitor nutri-thermocline depth in the tropical Atlantic (Molfino and McIntyre, 1990a, b), in the Western Tropical Atlantic (Kinkel et al., 2000; Bassinot et al., 1997), as well as in the other parts of the ocean (Okada and Honjo, 1973; Young, 1994; Okada and Wells, 1997; Wells and Okada, 1997; Beaufort et al., 1997, 1999, 2001, 2003; Beaufort and Buchet, 2003; Flores et al., 2000; Liu and Herbert, 2004; Baumann and Freitag, 2004; López-Otálvaro et al., 2008).

\section{Correspondence to:}

G.-E. López-Otálvaro

(gatsbyemperatriz@usal.es)

Published by Copernicus Publications on behalf of the European Geosciences Union. 
The production and sedimentation of coccolith-derived calcite in the deep ocean plays an important role in the carbon cycle through photosynthesis and calcification (Westbroek et al., 1993; Marsh, 2003; Brand, 1994; Young, 1994; Steinmetz, 1994). These organisms are one of the most important contributors to carbonate sedimentation in the open ocean and in continental slopes (Milliman, 1993; Steinmetz, 1994), such as in the Guyana Basin (Shipboard Scientific Party, 2003), an area controlled by a setting of hemipelagic deposition. The Guyana Basin is located on the western side of the Tropical Atlantic Ocean. This region has been documented as the main route of interhemispheric heat flux exchange from the South to the North Atlantic.

Several published contributions have documented the significance of the calcareous nannofossil assemblages and other micropalaeontological groups as proxies of surface water mass dynamics and palaeoproductivity in the Western Tropical Atlantic (WTA). Molfino and McIntyre (1990a, b) proposed a model in which the nutri-thermocline topography is related to Trade wind dynamics in the equatorial Atlantic. They used the relative abundances of $F$. profunda species, with higher proportions of this species associated with a deep nutri-thermocline and lower proportions related to a shallow nutri-thermocline. The downcore records of coccoliths from the Western Tropical Atlantic reported by Kinkel et al. (2000) indicated a high interglacial palaeoproductivity and a shallow thermocline as compared to glacial stages and substages during the last climatic cycle. Bassinot et al. (1997) used comparative profiles of the relative abundance of $F$. profunda (those recorded by Kinkel et al., 2000) and carbonate accumulation rates to explain that a nutri-thermocline displacement drove palaeoproductivity and carbonate concentration, with the thermocline displacement responding to the close relationship between the dynamics of the Trade winds and the Intertropical Convergence Zone (ITCZ) from $930 \mathrm{Ka}$ to $685 \mathrm{Ka}$ in the Ceara Rise. Also in the Ceara Rise, Rühlemann et al. (2001) reconstructed the thermocline depth from planktonic foraminifer isotope gradients, and compared this to the terrigenous sediment content and the relative abundance of $F$. profunda (Kinkel et al., 2000). They suggested that low accumulation rates, during periods of shallower thermocline, indicate a higher primary production during interglacial substages of Marine Isotope Stage (MIS) 5. Using high resolution calcareous dinoflagellate cyst and organic carbon records, Vink et al. (2001) presented new evidence of interlatitudinal teleconnections between Tropical and North Atlantic Ocean during the past $58 \mathrm{Ka}$. The authors found that high accumulation rates of calcareous dinoflagellate cysts occurred somewhat before the northern Atlantic Heinrich Events, indicating that shifts in the zonality of the low-latitude winds would be partly responsible for the climatic variability related to those events. Vink et al. (2002) show high interglacial accumulation rates of Thoracosphaera heimii and calcareous dinocysts in the Western and Eastern Tropical Atlantic, when the proportions of $F$. profunda were reduced, the nutri-thermocline was shallowed and the nutrient supply was higher over the past $150 \mathrm{Ka}$.

Our work focuses on a high-resolution micropalaeontological analysis of the coccolithophore assemblage over the last climatic cycle (the last $155 \mathrm{Ka}$ ). The primary goal is to reconstruct the patterns of coccolithophore production and its relationship with fluctuations in the nutri-thermocline and ocean dynamics in the Guyana Basin (Fig. 1).

\section{Oceanographic setting}

The Guyana Basin is located in the area of annual shift of the ITCZ that moves between $10^{\circ} \mathrm{N}$ and $5^{\circ} \mathrm{S}$ (Müller-Karger, 1989). The northward or southward position of the ITCZ causes a significant impact on water discharge from the Amazon and Orinoco rivers, as well as variations in the direction and speed of the Guyana Current (GC) and the southeast Trade winds (Müller-Karger, 1989; Wilson et al., 2002; Ffield, 2005; Stramma et al., 2005) (Fig. 1).

During the boreal summer, the southeast Trade winds are stronger, and the South Equatorial Current (SEC) and the North Brazilian Undercurrent (NBUC, which brings salty water from the South Atlantic) are well developed (da Silveira et al., 1994; Stramma et al., 1995; and Masson and Delecluse, 2000). During that season, the westward displacement of the SEC pile up surface waters along the eastern coast of South America deepens the nutri-thermocline in the WTA (Hastenrath and Merle, 1987). When the SEC reaches South America, it splits into two branches: one turns southward, supplying the Brazilian current (BC), and the other one takes off towards the north and feeds the North Brazilian Current (NBC), which is called the Guyana Current (GC) when it reaches the Guyana Basin (Fig. 1).

The ITCZ is displaced to the northernmost position $\left(6^{\circ} \mathrm{N}-\right.$ $10^{\circ} \mathrm{N}$ ), generating a wet season north of $\sim 5^{\circ} \mathrm{N}$ (MüllerKarger and Aparicio-Castro, 1994). The NBC (or GC) is mostly retroflexed, contributing to the North Equatorial Countercurrent (NECC) between $5^{\circ} \mathrm{N}-10^{\circ} \mathrm{N}$ (MüllerKarger et al., 1988), allowing anticyclonic rings to enter the continental margin and pass northwestward to merge with the Orinoco River plume (Müller-Karger, 1989; Ffield, 2005). These eddies transport and advect the Amazon River plume and, together with the NBUC, develop a zone of minimum surface salinity, warm temperatures, and a shallower and stronger halocline, where the river flow is dispersed (Masson and Delecluse, 2000). The other component of the GC is directed to the North Atlantic, transporting relatively warmer and fresher waters via the Caribbean Sea (feeding Caribbean current, CC) and the Gulf of Mexico (where it supports the Gulf Stream, GS) (Showers and Bevis, 1988; Schmitz, 1995; Stramma and Schott, 1996; Lynch-Stieglitz et al., 1999).

During the boreal winter, the northeast Trade winds dominate and push the ITCZ to the southermost position $\left(0^{\circ}-\right.$ $\left.5^{\circ} \mathrm{S}\right)$, causing dry conditions in the north of South America. 


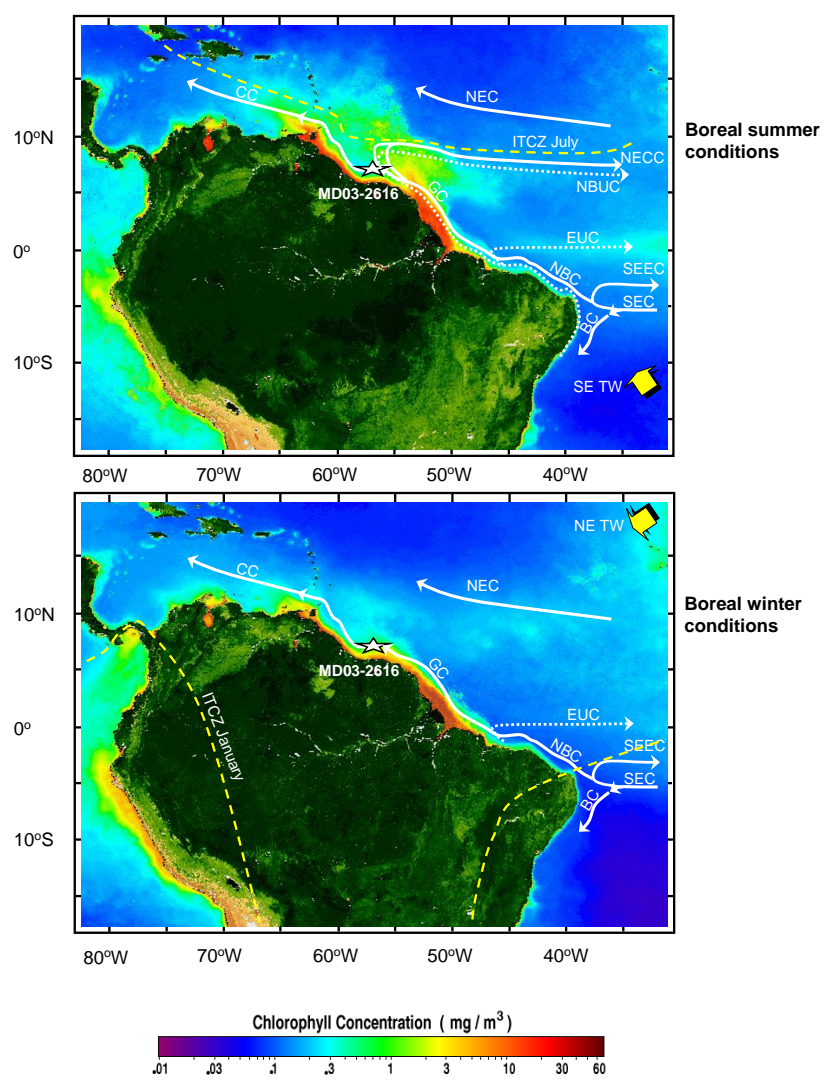

Fig. 1. Satellite images obtained from the SEAWIFS Program at the location of the Core MD03-2616. Hydrographic and atmospheric features in the Western Tropical Atlantic (WTA): Surface currents are indicated by continuous lines and subsurface currents are indicated by dotted lines. SEC: South Equatorial Current, BC: Brazilian Current, NBC: North Brazilian Current, CC: Caribbean Current, NECC: North Equatorial Counter Current, SECC: South Equatorial Counter Current, EUC: Equatorial Undercurrent, NBCU: North Brazilian Countercurrent, ITCZ: Intertropical Convergence Zone. (The hydrographic features were adopted from Richardson et al. (1994) and Haug et al. (2003). The image background was taken from http://oceancolor.gsfc.nasa.gov/SeaWiFS).

River plumes decrease in intensity, and together with the GC, are mostly driven into the coastal area, carrying relatively colder and saltier waters to the North Atlantic. During this season, the NBUC mainly feeds the Equatorial Undercurrent (EUC) at the equator and cannot cross the equator to the North Atlantic (Masson and Delecluse, 2000 and references therein). This atmosphere-ocean dynamics in the WTA plays a major role in the cross-equatorial heat flux to the North Atlantic (Ffield, 2005), producing relatively cooler surface waters south of the equator, and warmer surface waters north of the equator $\left(>24^{\circ} \mathrm{C}\right)$ in the WTA.

\section{Materials and methods}

\subsection{Core location and materials}

Core MD03-2616 was recovered in the Guyana Basin in the WTA $\left(7^{\circ} 48.75^{\prime} \mathrm{N}, 53^{\circ} 00.80^{\prime} \mathrm{W}\right)$ at a water depth of $1233 \mathrm{~m}$ during the PICASSO Cruise by the Marion Dufresne R/V (Fig. 1). This area is characterised by the influence of the Guyana current at the continental margin of French Guyana. The core shows an undisturbed high-quality sedimentary section of $39 \mathrm{~m}$ spanning the Pleistocene. It consists mainly of olive green silt and clay, rich in foraminifera and calcareous nannofossils, with slight bioturbation levels and high organic matter remains (Shipboard Scientific Party, 2003). Here, we focus on the uppermost $18 \mathrm{~m}$ (a detailed description was reported by the Shipboard Scientific Party, 2003).

\subsection{Age model and biostratigraphy}

The age-depth assignments are primarily based on 16 oxygen isotope control points determined on tests of the benthic foraminifer Uvigerina peregrina. Stable isotope analyses were performed using an automated carbonate preparation line coupled to a Finningan MAT 251 mass spectrometer at the Laboratoire des Sciences du Climat et de l'Environnement in Gif-sur-Yvette (France). Isotopic events were identified up to MIS $6(\sim 155 \mathrm{Ka})$, by comparison of the benthic $\delta^{18} \mathrm{O}$ from the Core MD03-2616 and the benthic $\delta^{18} \mathrm{O}$ stack of Lisiecki and Raymo (2005) (unpublished data, Fig. 2).

We analysed the $>150 \mu \mathrm{m}$ fraction to detect the qualitative abundance of planktonic foraminifer species typical of the WTA. A qualitative study of planktonic foraminifer biostratigraphy allowed the identification of the Ericson Climatic Biozones W1, X, Y, Z of Ericson and Wollin (1956) and the Y P. obliq. of Kennett and Huddlestun (1972). In our record, Biozone W1 was identified by the consistent and lower occurrence of the Globorotalia menardii group from the bottom $(155 \mathrm{Ka})$ of the section studied up to $133 \mathrm{Ka}$. This event was dated by Kenneth and Huddlestun (1972) from $150 \mathrm{Ka}$ to Termination II (128 Ka); i.e., slightly above ours. Biozone $\mathrm{X}$ was dated from $133 \mathrm{Ka}$ to the middle phase of substage $5 \mathrm{a}(84.3 \mathrm{Ka})$. Prell and Damuth (1978) reported the top of the Biozone $\mathrm{X}$ at $85 \mathrm{Ka}$; i.e. slightly below ours. The $G$. menardii complex is absent from Biozone $\mathrm{Y}$ (Ericson and Wollin, 1956; Kennett and Huddlestun, 1972), as we report here. The disappearance datum of Pulleniatina obliquiloculata $\left(\mathrm{Y}_{\text {P. obliq. }}\right.$ ) was recognised at $\sim 39 \mathrm{Ka}$, but this datum is diachronous across the tropical Atlantic (Prell and Damuth, 1978; Kennett and Huddlestun, 1972). Biozone Z was identified close to the end of MIS 2 (over the latest Wisconsin) in agreement with Kennett and Huddlestun (1972), although other authors have placed its bottom at the MIS $1 / 2$ boundary (Ericson and Wollin, 1956; Maslin and Mikkelsen, 1997) (Fig. 2). 


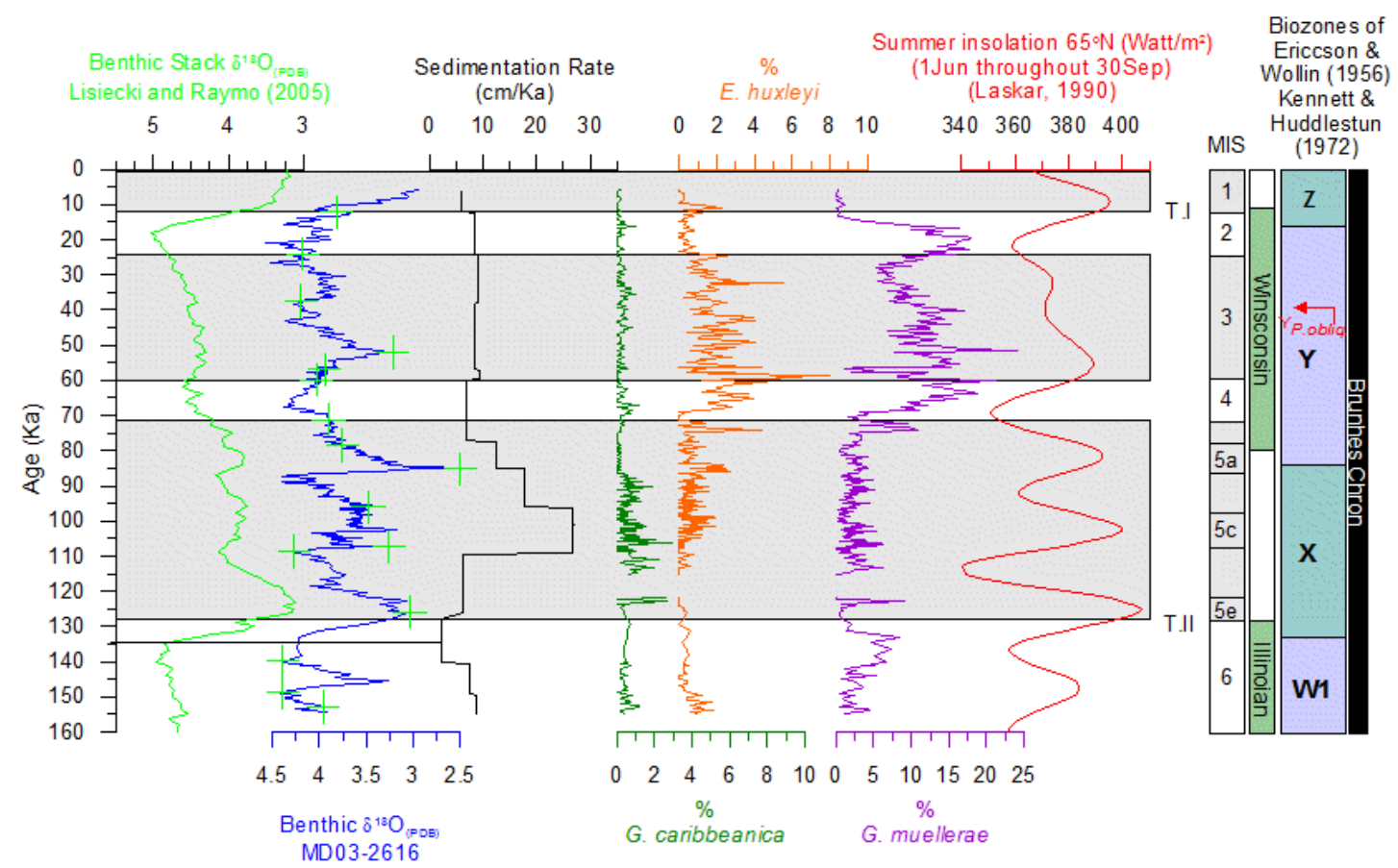

Fig. 2. Benthic $\delta^{18} \mathrm{O}$ stack record (PDB, Lisiecki and Raymo, 2005), benthic $\delta^{18} \mathrm{O}$ record (PDB) from Core MD03-2616 (unpublished data), sedimentation rates at Core MD03-2616, and the relative abundance (\%) of the specific index species from calcareous nannofossils at Core MD03-2616. Biozones X, Y, Z and W1 represent the biostratigraphic events of planktonic foraminifers identified at Core MD032616. The $\mathrm{Y}_{\text {P. obliq. }}$ biozone corresponds to the disappearance of Pulleniatina obliquiloculata. The green crosses in the $\delta^{18} \mathrm{O}$ record from Core MD03-2616 correspond to the control points used for constructing the chronostratigraphic framework at Core MD03-2616. Grey bars indicate interglacial marine isotope stages 1 through 5. 5a, 5b, 5c, 5d, 5e correspond to the substages of MIS 5. The Wisconsin and Illinoian episodes correspond to the Ice Ages between $12 \mathrm{Ka}$ and $80 \mathrm{Ka}$ in the former and $128 \mathrm{Ka}$ and $310 \mathrm{Ka}$ in the latter. T.I $=$ Termination I, T.II $=$ Termination II. MIS: Marine Isotope Stage.

According to currently available data, the reversal in the abundance of the coccolithophore species Emiliania huxleyi and Gephyrocapsa muellerae is not clear. Thierstein et al. (1977) placed this datum at around 73-85 Ka. The absence of Pseudoemiliania lacunosa, the relatively low abundance of Gephyrocapsa caribbeanica species (less than 3\%), and the occurrence of both E. huxleyi and G. muellerae along the interval studied suggest that our sediment sequence is younger than $268 \mathrm{Ka}$ (Fig. 2).

\subsection{Slide preparation and counting techniques}

Slides were prepared following the decantation technique outlined by Flores and Sierro (1997) to obtain quantitative measurements (coccoliths per gram and accumulation rates of coccoliths). These slides were analysed at a 4-cm spacing (representing approximately $\sim 0.120 \mathrm{Ka}$ to $\sim 0.700 \mathrm{Ka}$ ) with a polarised microscope at $1000 \mathrm{X}$ magnification. 380 samples were examined, and more than 500 coccoliths were counted on each slide in order to identify the coccolith assemblage quantitatively.

We estimated variations in the $\mathrm{N}$ ratio (modified from Flores et al., 2000; López-Otálvaro et al., 2008), which is a func- tion based on the relative proportion of taxa usually living in the upper photic zone (small Noelaerhabdaceae, E. huxleyi and Gephyrocapsa oceanica; e.g., Okada and Honjo, 1973; Okada and McIntyre, 1979; Giraudeau, 1992; Young, 1994; Okada and Wells, 1997; Wells and Okada, 1997; Flores et al., 1999, 2000, 2003; Bollman et al., 1998; Beaufort et al., 1999; Beaufort and Buchet, 2003; Hagino and Okada, 2004) versus the lower photic zone dwellers ( $F$. profunda; e.g., Okada and Honjo, 1973; Okada and McIntyre, 1977; Molfino and McIntyre, 1990a, b). High $\mathrm{N}$ ratio values (close to 1) indicate a high production of upper photic species against the production of lower photic species as the result of a shallow nutrithermocline. Low $\mathrm{N}$ ratio values (close to 0 ) reveal a proliferation of $F$. profunda, in agreement with a deep stratification and a deep nutri-thermocline (Okada and Honjo, 1973; Okada, 1980; Molfino and McIntyre, 1990a, b; Wells and Okada, 1997; Flores et al., 2000). The accumulation rate of coccoliths (NAR, liths $\mathrm{cm}^{-2} \mathrm{Ka}^{-1}$ ) has been widely used by several authors as a reference for high palaeoproductivity of coccolithophores and particle flux out of the mixed layer (Steinmetz, 1994 and references therein; Su, 1996; Baumann et al., 2004). This parameter was estimated following the standard method of Flores and Sierro (1997), and it involves 
Table 1. Taxonomic notes and morphological differences used for the genus Gephyrocapsa (mainly adopted from Flores et al., 2000) in this study.

\begin{tabular}{|c|c|c|c|c|}
\hline Present work & $\begin{array}{l}\text { Small Gephyrocapsa } \\
\text { (it includes } G . \text { ericsonii } \\
\text { and } G . \text { aperta) }\end{array}$ & $\begin{array}{l}\text { G. muellerae } \\
\text { (it includes } G . \text { margereli) }\end{array}$ & G. caribbeanica & $\begin{array}{l}\text { G. oceanica } \\
\text { (it includes G. oceanica } \\
\text { and large Gephyrocapsa) }\end{array}$ \\
\hline Coccolith length & $\begin{array}{l}<3 \mu \mathrm{m}(G . \text { ericsonii }) \\
<2.5 \mu \mathrm{m}(G . \text { aperta })\end{array}$ & $>3 \mu \mathrm{m}$ & $>3 \mu \mathrm{m}$ & $\begin{array}{l}\text { 3-4 } \mu \mathrm{m}(\text { (G. oceanica) and } \\
4-5 \mu \mathrm{m} \text { (large Gephyrocapsa) }\end{array}$ \\
\hline Bridge angle & & $5^{\circ}-40^{\circ}$ & Central area closed & $>50^{\circ}$ \\
\hline \multicolumn{5}{|l|}{ Author equivalence } \\
\hline Thierstein et al., 1977 & & G. caribbeanica & & \\
\hline Raffi et al., 1993 & Small Gephyrocapsa & Small Gephyrocapsa & Small Gephyrocapsa & Medium Gephyrocapsa \\
\hline Bollmann, 1997 & G. minute & $G$. cold & $G$. oligotrophic, $G$. transitional & $G$. large, $G$. equatorial \\
\hline Flores et al., 2000 & Small Gephyrocapsa & G. muellerae & G. caribbeanica & G. oceanica \\
\hline Baumann and Freitag, 2004 & G. ericsonii/G. aperta & G. muellerae/G. margereli & G. caribbeanica & G. oceanica \\
\hline
\end{tabular}

knowing the absolute abundances of coccoliths, the sedimentation rate, and the dry sediment bulk density. The species identified are listed in Appendix A.

\subsection{Taxonomic information}

The systematic classification of coccoliths is based on their morphology. The morphological differences used for the genus Gephyrocapsa were adopted from Flores et al. (2000) and are summarised in Table 1. Small placoliths (such as Gephyrocapsa aperta and Gephyrocapsa ericsonii, small Reticulofenestra and E. huxleyi) with an open or closed central area and smaller than $3 \mu \mathrm{m}$ were classified together in the group of small Noelaerhabdaceae. Gephyrocapsa spp. contain Gephyrocapsa species larger than $3 \mu \mathrm{m}$ such as G. oceanica, G. muellerae, and G. caribbeanica. Different sizes of $G$. oceanica were counted separately (medium Gephyrocapsa 3-4 $\mu \mathrm{m}$ and large Gephyrocapsa $4-5 \mu \mathrm{m}$ ), but later these sizes were lumped together as G. oceanica for palaeoecological purposes. Additionally, Calciosolenia murrayi, Discosphaera tubifera, Neosphaera coccolithomorpa, Oolithotus spp., Pontosphaera spp., Rhabdosphaera clavigera, Syracosphaera spp., Umbellosphaera spp. and Umbilicosphaera spp. were included as the group of warm taxa (Hiramatsu and De Deckker, 1997; Böeckel and Baumann, 2004). The genus Umbilicosphaera includes Umbilicosphaera hulburtiana, Umbilicosphaera sibogae var. foliosa and Umbilicosphaera sibogae var. sibogae. The marked dominance of $U$. siboage var. sibogae (hereafter $U$. sibogae) in the group of the warm taxa suggests that its palaeoecological behaviour in Guyana Basin should be analysed. Calcidiscus leptoporus and Helicosphaera spp. species are characterised by their lower abundances and poor consistence along the record studied. Helicosphaera spp. mainly include Helicosphaera carteri, and in a much lower proportion, Helicosphaera pavimentum $(<0.5 \%)$, but we only used the record of $H$. carteri for palaeoecological purposes.

\section{Preservation}

The dissolution of the calcareous nannofossil assemblage was estimated through the CEX' index (Fig. 3). That index provides a qualitative record of the coccolith lysocline position (Dittert et al., 1999; Böeckel and Baumann, 2004; Böeckel et al., 2006). Higher CEX' values (close to 1) point to a better preservation of the coccoliths, while lower CEX' values (close to 0 ) point to coccolith carbonate dissolution (Fig. 3).

This ratio was originally based on the relationship of delicate coccoliths of E. huxleyi versus the stronger calcified coccoliths of C. leptoporus (CEX index, Dittert et al., 1999). Later, the CEX index was modified by Böeckel and Baumann (2004) to include other fragile species such as G. ericsonii, and was designated CEX'. We employed the CEX' index, including the most fragile species such as: G. ericsonii, E. huxleyi and small Reticulofenestra $(<3 \mu \mathrm{m})$, since calcareous nannofossil analysis under the light microscope does not allow identification of specimens smaller than $3 \mu \mathrm{m}$ at the species level. It is difficult to separate G. ericsonii which has lost its bridge from small Reticulofenestra. Although the highly calcified $G$. aperta species was not included in the CEX' index, we still maintained the original concept of relating delicate coccoliths versus $C$. leptoporus.

The overall preservation of coccoliths was good along the last climatic cycle, except during the end of MIS 5e and MIS 5d, which showed a stronger dissolution and barren intervals; and during the middle of MIS 5b, which showed an intermediate level between moderate to poor preservation. Decreases in the CEX' index and marked increases in the relative abundances of the most resistant species in the assemblage ( $G$. oceanica and $F$. profunda) confirmed severe dissolution during the late MIS 5e and during MIS 5d (Fig. 3). 


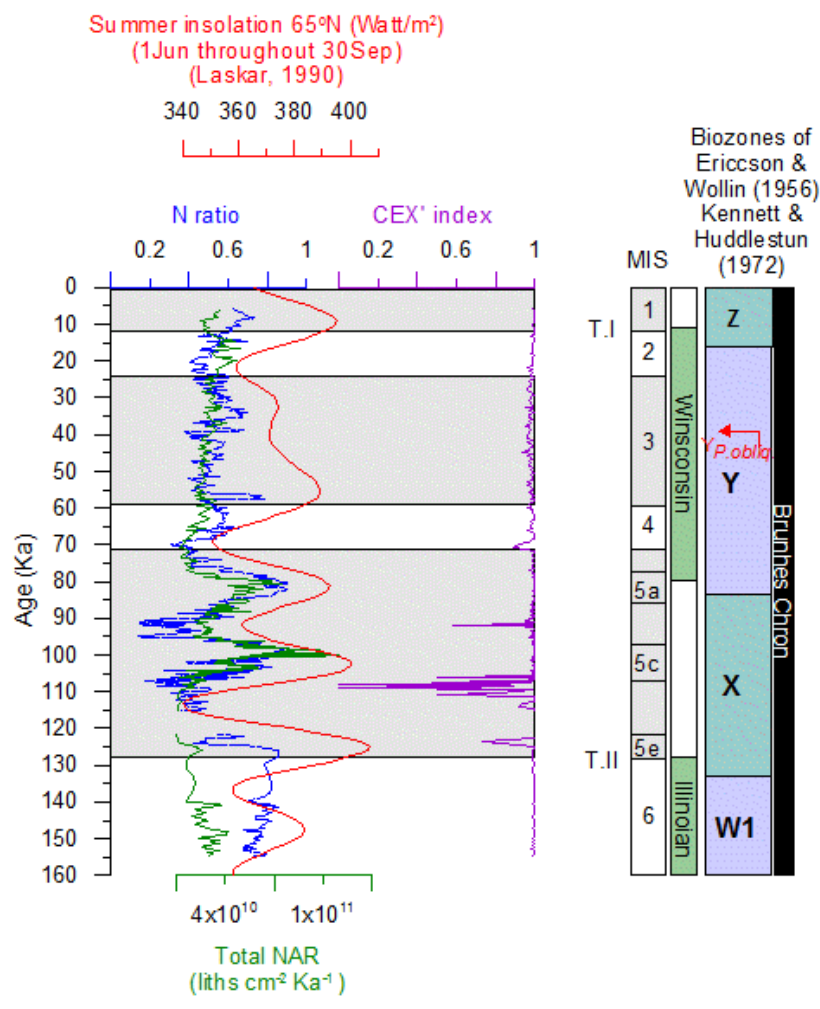

Fig. 3. Review of the bioproductivity proxies used for Core MD032616: $\mathrm{N}$ ratio vs. total nannofossil accumulation rates (NAR, liths $\left.\mathrm{cm}^{-2} \mathrm{Ka}^{-1}\right)$. Grey bars indicate interglacial marine isotope stages 1 through 5. 5a, 5b, 5c, 5d, 5e correspond to the substages of MIS 5. The Wisconsin and Illinoian episodes correspond to the Ice Ages between $12 \mathrm{Ka}$ and $80 \mathrm{Ka}$ in the former, and $128 \mathrm{Ka}$ and $310 \mathrm{Ka}$ in the latter. T.I = Termination I, T.II = Termination II.

\section{Results}

\subsection{Variations in the assemblage}

The small Noelaerhabdaceae, F. profunda and G. oceanica proved to be the dominant species in the coccolithophore assemblage. G. muellerae (Table 1) and U. sibogae species were identified as important secondary components. Helicosphaera spp. and C. leptoporus were considered subordinate species because they were present in lower proportions (lesser than 2\%) along the record studied (Fig. 4).

The most prominent feature of the coccolith record was the inverse relationship between small Noelaerhabdaceae and $F$. profunda. Maximum proportions and the NAR values of the small Noelaerhabdaceae were found during interglacial substages ( $80 \%$ and $1 \times 10^{11}$ liths $\mathrm{cm}^{-2} \mathrm{Ka}^{-1}$ respectively). Higher proportions of $F$. profunda occurred during glacial substages of MIS 5 (80\%) but its specific NAR values were observed between MIS $5 \mathrm{c}$ to $5 \mathrm{a}\left(3 \times 10^{10}\right.$ liths $\left.\mathrm{cm}^{-2} \mathrm{Ka}^{-1}\right)$. Conversely, during MIS 4 and extending to the early Holocene, those taxa exhibit less amplitude (lower gradients) but more frequent variability in their relative abundances and in their lower specific NAR values. F. profunda dominates the assemblage during MIS 4 to the middle of MIS 2, with mean values close to $45 \%$. F. profunda-specific NAR values show a slight increasing trend towards MIS 2, then declining during the early Holocene. Small Noelaerhabdaceae reach higher proportions from the middle of MIS 2 to the early Holocene (up to $60 \%$ ).

G. oceanica, U. sibogae, C. leptoporus and H. carteri also show common stronger NAR gradients during MIS 5. Their specific NAR values follow those of small Noelaerhabdaceae during that stage. The relative abundances of $G$. oceanica exceed $30 \%$ when the assemblage underwent stronger dissolution (the end of MIS 5e and during MIS 5d; Fig. 4). Other important proportion peaks of $G$. oceanica were recorded during MIS 3a. U. sibogae also shows higher relative abundances during MIS 4 and 3, and C. leptoporus during MIS 3.

The overall trend of all species-specific NAR values reveals steadier values during MIS 4 to MIS 2 and point to a declining trend during the early Holocene (except those of small Noelaerhabdaceae).

\subsection{Variations in the $\mathrm{N}$ ratio and total NAR profiles}

The variation in total NAR parallels that of the $\mathrm{N}$ ratio, indicating higher amplitude changes between the interglacial and glacial substages of MIS 5 (with values between 0.9 and 0.2 for the $\mathrm{N}$ ratio and, $1.2 \times 10^{11}$ and $1 \times 10^{10}$ liths $\mathrm{cm}^{-2} \mathrm{Ka}^{-1}$ for the total NAR). Frequent and mild fluctuations in the $\mathrm{N}$ ratio and total NAR occur throughout MIS 4-2 and the early Holocene. These profiles are comparable to those observed at the end of MIS 5b (Fig. 4). Such parameters are strongly influenced by the dominant species in the assemblage and in consequence display low gradients during glacial MIS 42 (Figs. 3 and 4). Thus, the variation in N ratio and NAR records reveals two different hydrographic scenarios during the last climatic cycle: the first starts at the end of MIS 6 to MIS 5, and the second spans MIS 4 to the early Holocene.

\section{Discussion}

\subsection{Latitudinal changes in the ITCZ and productivity of coccolithophores: the Northern Hemisphere con- nection}

Our data indicate a lower primary production and a deep stratified photic layer during the glacial substages of the last climatic cycle (Figs. 1, 3 and 4). This scenario is linked to a southward displacement of the ITCZ and the northeast Trade winds, which blew perpendicularly to the Guyana coast, favouring the piling up of warm surface waters dragged by the NEC along this coast. As a result, the nutri-thermocline was depressed, preventing the coastal upwelling and hence, the inflow of nutrient rich and cooler waters to the euphotic zone. These atmospheric and hydrological conditions are similar to those prevailing today during the boreal winter, 


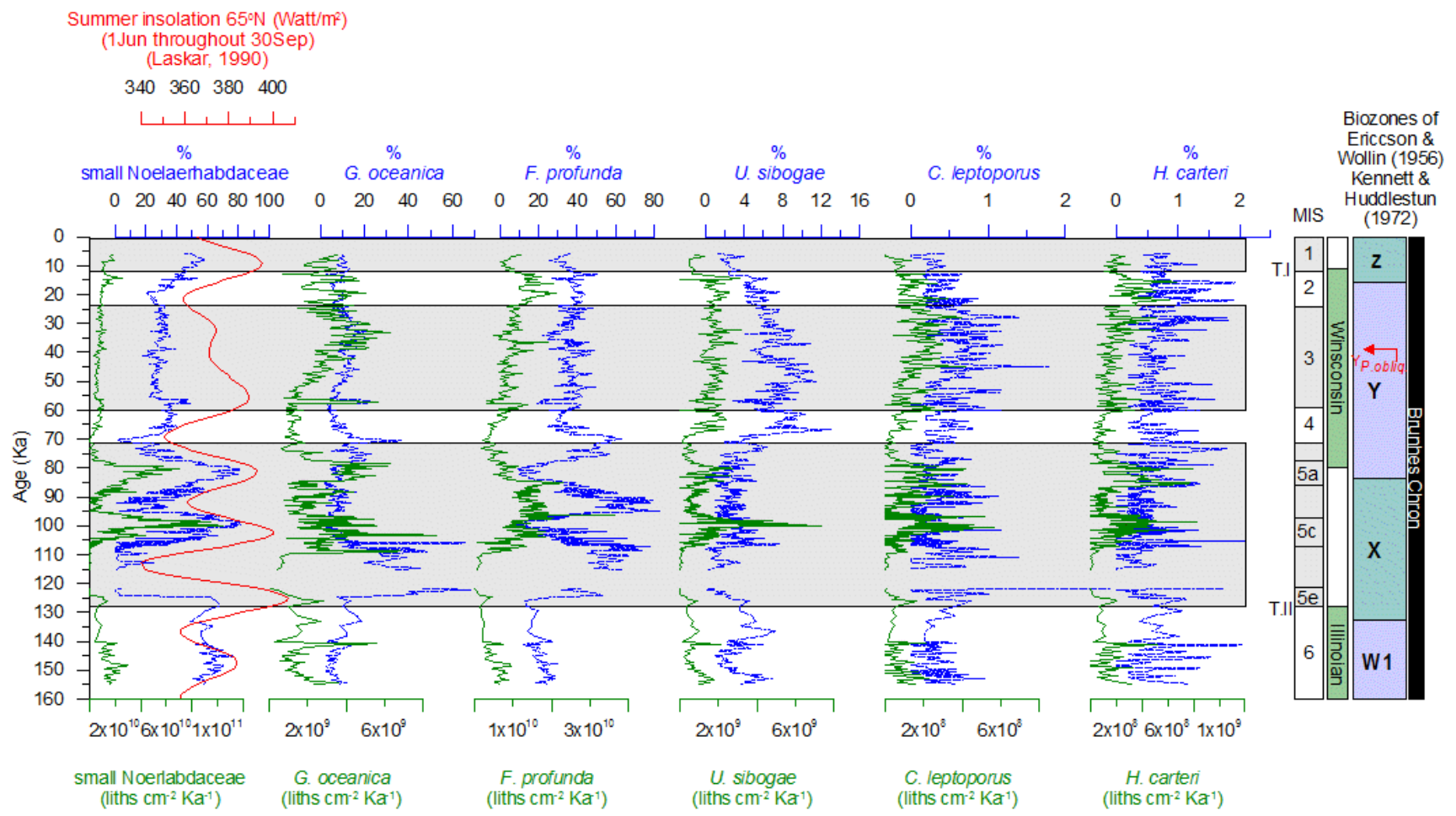

Fig. 4. Relative calcareous nannofossil abundances (\%) and nannofossil accumulation rates (NAR, liths cm ${ }^{-2} \mathrm{Ka}^{-1}$ ). Grey bars indicate interglacial marine isotope stages 1 through 5 . 5a, 5b, 5c, 5d, 5e correspond to the substages of MIS 5. The Wisconsin and Illinoian episodes correspond to the Ice Ages between $12 \mathrm{Ka}$ and $80 \mathrm{Ka}$ in the former, and $128 \mathrm{Ka}$ and $310 \mathrm{Ka}$ in the latter. T.I = Termination I, T.II = Termination II.

when the ITCZ is placed between $0^{\circ}$ to $5^{\circ} \mathrm{S}$ (Müller-Karger, 1989; well south of the Guyana Basin) and the northeast Trade winds blow onshore (Gibbs, 1980). Several authors have indicated severe Northeast Trade winds and a southward latitudinal migration of the atmospheric and hydrographic circulation in the WTA during glacial substages of MIS 3 and during MIS 2 (Balsam et al., 1995; Harris and Mix, 1999; Broccoli, 2000; Peterson et al., 2000; Vink et al., 2001, 2002). Indeed, a southward displacement of $8^{\circ}$ for the ITCZ during MIS 2 has been reported (Kolla et al., 1979).

In contrast, a higher primary production and eutrophic conditions are recorded during the interglacial substages of the last climatic cycle; primarily the result of coastal upwelling induced by a northward migration of the ITCZ. The ITCZ shift would have run parallel to the coast of northeastern South America, channeling the southeast Trade winds along the coast (Figs. 1, 3 and 4). That along-shore wind vector favoured eastward water transport through a welldeveloped NECC (Fig. 1). During those episodes, the piling up of warmer waters in the Guyana Basin was reduced because the area studied was outside the influence of the northeast Trade winds. This scenario is similar to that prevailing today in the Guyana Basin during the boreal summer. The northward displacement of the ITCZ $\left(6^{\circ} \mathrm{N}-10^{\circ} \mathrm{N}\right)$ and the southeast Trade winds induce coastal upwelling in the Guyana basin during the summer, favouring the development of the NBC retroflection (Ryther et al., 1967; Hulburt and Corwin, 1969; Müller-Karger et al., 1989, 1995) and the formation of the NECC between $5^{\circ} \mathrm{N}-8^{\circ} \mathrm{N}$, which transports warm water offshore (Busalacchi and Picaut, 1983). Gibbs (1980), Pujos and Froidefond (1995, and references therein) have reported seasonal scenarios where the southeast Trade winds prevail over northeast Trades and blow alongshore the Guyana coast during the boreal summer, promoting coastal upwelling in the basin. Colour reflectance and chemical data from the Cariaco Basin (Peterson et al., 2000) and micropalaeontological data from the Tobago Basin (Vink et al., 2001) are consistent with a northward shift of the ITCZ during interglacial substages of MIS 3. Titanium and iron contents in the sediments from the Cariaco Basin also suggest a northward position of the ITCZ during the early Holocene (Haug et al., 2001).

Along the same line of evidence, the micropalaeontological signal also indicates that maximum palaeoproductivity, and hence a shallower nutri-thermocline, occurred during the interglacial substages of MIS 6-5 compared with those of MIS 4-2 and with the early Holocene. This situation points to a relatively stronger coastal upwelling in the Guyana Basin 
during interglacial substages of MIS 6-5, induced by the northernmost position of the ITCZ during the same episodes.

High productivity and a shallow nutri-thermocline in the Guyana Basin occurred at times of maximum summer insolation at $65^{\circ} \mathrm{N}$ (mean insolation from 1 June to 30 September). This correlation suggests a close connection between the Northern Hemisphere (NH) summer insolation, the migration of the nutri-thermocline, the Trade wind dynamics, and the latitudinal shift of the ITCZ. Latitudinal changes in the ITCZ and the associated rain belt are driven by the meridional wind component, which in turn is the response to sea surface temperature and salinity gradients between the high and low latitudes in the NH (Hastenrath and Druyan, 1993; Hastenrath and Greischar, 1993). Such gradients, and the subsequent changes in Trade winds intensity, are the result of $\mathrm{NH}$ ice-sheet expansions or retreats induced by variations in the NH summer insolation (Khodri et al., 2003; Chiang et al., 2003). Besides the coincidence in the phase between palaeoproductivity and $65^{\circ} \mathrm{N}$ summer insolation, changes in the amplitude of both records are also related. Higher amplitude changes in palaeoproductivity and insolation during the substages of MIS 5 contrast with lower amplitude changes during the substages of MIS 4-2.

Our results support previous records from the WTA (Kinkel et al., 2000), which record a shallow nutricline and high coccolithophore productivity along interglacial times and a deeper nutri-thermocline along the glacial stages and substages. Geochemical and sedimentological evidence from the Ceara Rise also supports a shallow nutri-thermocline during interglacial substages along the last climatic cycle (Rühlemann et al., 2001). By contrast, in the eastern tropical Atlantic, Molfino and McIntyre (1990a, b) and Wolff et al. (1999) reported a shallow nutri-thermocline during glacial periods that was controlled by the Trade winds.

Variations in the position of the thermocline have been reported by Hüls and Zahn (2000) and Vink et al. (2001) in a nearby core taken from the Tobago Basin. They found the shallowest thermocline for MIS $3(\sim 50 \mathrm{~m})$ as compared with the glacial MIS $2(\sim 80 \mathrm{~m})$ and the Holocene $(\sim 150 \mathrm{~m})$, the latter being closer to its current position at the location where our core was retrieved (150 m, Pailler et al., 1999).

\subsection{River runoff}

The main freshwater source that affects the WTA is the Amazon River, which is mostly responsible for the low sea surface salinity in the WTA (Masson and Delecluse, 2000), since the waters of the Orinoco flow downstream towards the Caribbean Sea (Ffield, 2005). Several authors (MüllerKarger et al., 1989 and references therein; Peterson et al., 2000) have indicated that high abundances of phytoplankton are associated with higher seasonal river runoffs and lower salinities in the northern Caribbean Sea $\left(14^{\circ} \mathrm{N}\right.$ and $\left.18^{\circ} \mathrm{N}\right)$ than in the typical waters of the WTA.
The association in temperature and pressure gradients between low and high latitudes, and the ITCZ position cited above accounts for the relationship between cold/warm periods in high latitudes in the North Atlantic and drier/wetter conditions over northern South America (Haug et al., 2001). The northward position of the ITCZ during the interglacial substages over the last climatic cycle favoured the influx of river nutrients to the ocean and the configuration of an oceanic system that supported a superficial nutri-thermocline and consequently increased biological productivity in the Cariaco Basin (Peterson et al., 2000), Trinidad Basin (Vink et al., 2001), and Caribbean Sea (Martínez et al., 2007). Similarly, Showers and Bevis (1988) documented an increase in the Amazon River runoff during Termination I up to 6$5 \mathrm{Ka} \mathrm{BP}$ ago. Other authors have reported the southward geographic situation of the ITCZ over the last glacial and consequently drier conditions over northern South America (Kolla et al., 1979; Balsam et al., 1995; Peterson et al., 2000), together with decreases in the influence of the river flow system and a deeper nutri-thermocline that reduced bioproductivity (Peterson et al., 2000; Vink et al., 2000, 2001, 2002).

According to these suggestions and the chlorophyll concentration data (primary productivity distribution) presented by SeaWIFS Project imagery (Fig. 1), the influence of an enhanced nutrient supply by rivers in the production of coccolithophores cannot be completely ruled out. However, within the association of calcareous nannoplankton there is no clear indicator able to account for a greater discharge from the Amazon during the interglacials, e.g., reworked coccolith individuals or even freshwater-related species (phytoliths or freshwater diatoms), and there is no evidence in the association of low sea surface salinity. U. sibogae has been directly related to surface water salinity in the North Pacific (Roth and Coulbourn, 1982), and has been found in warm oligotrophic waters (Okada and McIntyre, 1979; Roth, 1994; Young, 1994; Böeckel and Baumann, 2004; Ziveri et al., 2004), but also in medium-to-high fertility waters (Roth and Berger, 1975; Roth and Coulbourn, 1982), with temperatures ranging from $18^{\circ} \mathrm{C}$ to $25^{\circ} \mathrm{C}$ (McIntyre and Bé, 1967; Okada and McIntyre, 1979). G. oceanica has also been observed in relatively warm, highly saline and fertile waters (Winter, 1982, 1985; Mitchell-Innes and Winter, 1987). H. carteri has been recorded during low salinity and turbid water settings (Colmenero-Hidalgo et al., 2004) and also in eutrophic (Ziveri et al., 1995; Ziveri et al., 2000; Andruleit and Rogalla, 2002; Findlay and Giraudeau, 2002; Ziveri et al., 2004; Baumann et al., 2005) and oligotrophic (Haidar and Thierstein, 1997; Giunta et al., 2003) environments. The palaeocological preference of $C$. leptoporus has been related to elevated nutrient levels (Roth and Berger, 1975; Fincham and Winter, 1989; Andruleit and Rogalla, 2002; Flores et al., 2003) and also to more oligotrophic and warmer conditions (Flores et al., 1999; Baumann et al., 2004; Ziveri et al., 2004; Marino et al., 2008). However, U. sibogae, G. oceanica, H. carteri and $C$. leptoporus do not show a systematic correspondence 
to temperature or salinity. This implies that $U$. sibogae, $G$. oceanica, H. carteri and C. leptoporus respond to a productivity pattern rather than to a pattern of temperature or salinity, especially significant in MIS 4-2 (Fig. 3).

\subsection{Dissolution of coccoliths}

Coccolith dissolution episodes (Figs. 3 and 4) suggest either a shallowing of the lysocline or dissolution above the lysocline. Curry and Cullen (1997) have documented high carbonate dissolution during glacial periods in response to deep water mass changes at greater depths in the WTA $(>3000 \mathrm{~m}$ water depth). Owing to the shallow depth position of Core MD03-2616, dissolution below the lysocline can be ruled out, because aragonite and calcite lysoclines have been reported at 2200 and $4000 \mathrm{~m}$, respectively (in Vink et al., 2001). Dissolution above the lysocline may be a response to the acidification of interstitial waters due to the oxidation of organic matter within the sediments. However, this hypothesis is not supported by the available observations, and hence its confirmation requires detailed benthic isotope $\delta^{13} \mathrm{C}$ data, sedimentological studies, and further oceanographic reconstructions in the Guyana Basin.

\section{Conclusions}

The evolution of the coccolithophore assemblage in the Guyana Basin was mainly driven by changes in the productivity pattern. The NAR record resembles that of the $\mathrm{N}$ ratio, suggesting that the NAR is also indicative of variations in palaeoproductivity.

High palaeoproductivity and a shallow nutri-thermocline during interglacial substages over the past $155 \mathrm{Ka}$ resulted from the dominant southeast Trade winds that displaced the ITCZ to a northward position and blew parallel to the coast, causing an upwelling of cool waters. Decreases in palaeoproductivity during glacial substages were related to a southward movement of the ITCZ. In consequence, the dominant northeast Trade winds blew perpendicular to the coast, causing the piling up of warm waters and a deepening of the nutrithermocline.

The production of coccolithophores and the shifting of the nutri-thermocline covary with summer insolation at high northern latitudes. Low palaeoproductivity is recorded during periods of low northern summer insolation (glacial substages of the last climatic cycle), indicating that during times of higher ice volume, the northeast Trade winds were enhanced, moving the ITCZ southward and causing a deepening of the nutri-thermocline in the Guyana Basin. High palaeoproductivity is recorded during times of high Northern Hemisphere insolation (interglacial substages over the last climatic cycle), suggesting that southeast Trade winds prevailed over the northeast Trades and moved the ITCZ northward, favouring coastal upwelling and a shallow nutrithermocline.

The micropalaeontological data reveal that the highest palaeoproductivity and, hence, the shallowest nutrithermocline occurred during the interglacial substages of MIS 6-5 compared with those episodes of MIS 4-2 and with the early Holocene.

A northern position of the ITCZ during interglacial times would imply a higher annual rainfall and river runoff to the Guyana Basin. Consequently, times of higher palaeoproductivity should be related to episodes of greater runoff. Nevertheless, the coccolithophore assemblage does not seem to record changes in salinity. However, the influence of continental-derived nutrients and a freshening of surface water masses through the Amazon River runoff cannot be ruled out.

\section{Appendix A}

\section{Taxonomic appendix}

- Calcidiscus leptoporus (Murray and Blackman, 1898; Loeblich and Tappan, 1978)

- Calciosolenia murrayi (Gran, 1912)

- Discosphaera tubifera (Murray and Blackman, 1898) (Ostenfeld, 1900) [Rhabdosphaera]

- Emiliania huxleyi (Lohmann, 1902; Hay and Mohler in Hay et al., 1967)

- Florisphaera profunda (Okada and Honjo, 1973)

- Gephyrocapsa aperta (Kamptner, 1963)

- Gephyrocapsa caribbeanica (Boudreaux and Hay, 1967)

- Gephyrocapsa ericsonii (McIntyre and Bé, 1967)

- Gephyrocapsa muellerae (Bréhéret, 1978)

- Gephyrocapsa oceanica (Kamptner, 1943)

- Helicosphaera carteri (Wallich, 1877; Kamptner, 1954)

- Neosphaera coccolithomorpha (Lecal-Schlauder, 1950) 
- Oolithotus

(Cohen, 1964; Reinhardt, in Cohen and Reinhardt, 1968)

\section{- Pontosphaera}

(Lohmann, 1902)

- Pseudoemiliania lacunosa

(Kamptner, 1963; Gartner, 1969)

- Rhabdosphaera clavigera

(Murray and Blackman, 1898)

- Reticulofenestra

(Hay, Mohler and Wade, 1966)

- Syracosphaera

(Lohmann, 1902)

- Umbellosphaera

(Paasche, in Markali and Paasche, 1955)

- Umbilicosphaera hulburtiana

(Gaarder, 1970)

- Umbilicosphaera sibogae var. foliosa

(Kamptner, 1963; Okada and McIntyre, 1977)

- Umbilicosphaera sibogae var. sibogae

(Weber-van Bosse, 1901; Gaarder, 1970)

Acknowledgements. The research discussed here was supported by Spanish projects CGL2005-00642/BTE, CGL2006-10593 from the Ministerio de Educación y Ciencia, A008C05 from the Consejería de Educación de la Junta de Castilla y León and by the Spanish Grant BES-2003-0010 from the Ministerio de Educación y Ciencia to G.-E. López-Otálvaro. We also gratefully thank Maria Angela Bassetti, Gabriel Filippelli and one anonymous reviewer for their useful comments.

Edited by: S. Spezzaferri

\section{References}

Andruleit, H. A. and Rogalla, U.: Coccolithophores in surface sediments of the Arabian Sea in relation to environmental gradients in Surface waters, Mar. Geol., 186, 505-526. 2002.

Balsam, W. L., Otto-Bliesner, B. L., and Deaton, B. C.: Modern and last glacial maximum eolian sedimentation patterns in the Atlantic Ocean interpreted from iron oxide content, Paleoceanography, 10, 493-507, 1995.

Bassinot, F. C., Beaufort, L., Vincent, E., and Labeyrie, L.: Changes in the dynamics of Western Equatorial Atlantic surface currents and biogenic productivity at the "Mid-Pleistocene Revolution" ( $\sim 930 \mathrm{Ka})$ : Leg 154, in: Proc. ODP, Sci. Results, 154, edited by: Shackleton, N. J., Curry, W. B., Richter, C., and Bralower, T. J., College Station, TX (Ocean Drilling Program), 269-284, 1997.

Baumann, K.-H. and Freitag, T.: Pleistocene fluctuations in the northern Benguela Current systems as revealed by coccolith assemblages, Mar. Micropaleontol., 52, 195-215, 2004.

Baumann, K.-H., Böeckel, B., and Frenz, M.: Coccolith contribution to South Atlantic carbonate sedimentation, in: Coccolithophores - From Molecular Processes to Global Impact, edited by: Thierstein, H. and Young, J., Springer-Verlag, 367-402, 2004.

Baumann, K.-H., Andruleit, H., Bockel, B., Geisen, G., and Kinkel, H.: The significant of extant coccolithophores as indicators of ocean water masses, surface water temperature, and paleoproductivity: a review, Paläontologische Zeitschrift 79, 93-112, 2005.

Beaufort, L. and Buchet, N.: Variability of specific coccolith $\mathrm{CaCO}_{3}$ weight, and primary production in the western Pacific warm pool during the last glacial cycle, Geophys. Res. Abstr., 5, 13225, 2003.

Beaufort, L, Lancelot, Y., Camberlin, P., Cayre, O., Vincent, E., Bassinot, F., and Labeyrie, L.: Insolation Cycles as a Major Control of Equatorial Indian Ocean Primary Production, Science, 278, 1451-1454, 1997.

Beaufort, L., Bassinot, F. C., and Vincent, E.: Primary production response to orbitally induced variations of the Southern Oscillation in the Equatorial Indian Ocean, in: Reconstructing Ocean History: a Window into the Future, edited by: Abrantes, F. and Mix, A. C., Kluwer Academic/Plenum, New York, 245-272, 1999.

Beaufort, L., de Garidel-Thoron, T., Mix, A. C., and Pisias, N. G. ENSO-like Forcing on Oceanic Primary Production During the Late Pleistocene, Science, 293, 2440-2444, 2001.

Beaufort, L., de Garidel-Thoron, T., Linsley B., Oppo, D., and Buchet, N.: Biomass burning and oceanic primary production estimates in the Sulu Sea area over the last $380 \mathrm{Ky}$ and the East Asian monsoon dynamics, Mar Geol 201, 53-65, 2003.

Böeckel, B. and Baumann, K.-H.: Distribution of coccoliths in surface sediments of the south-eastern South Atlantic Ocean: ecology, preservation and carbonate contribution, Mar. Micropaleontol., 51, 301-320, 2004.

Böeckel, B., Baumann, K.-H., Henrich, R., and Kinkel, H.: Coccolith distribution patterns in South Atlantic and Southern Ocean surface sediments in relation to environmental gradients, DeepSea Res., 53, 1073-1099. 2006.

Bollmann, L., Baumann, K.-H., and Thierstein, H.R.: Global dominance of Gephyrocapsa coccoliths in the Late Pleistocene: Selective dissolution, evolution or global environment change, $\mathrm{Pa}-$ 
leoceanography, 13, 517-529, 1998.

Brand, L. E.: Physiological ecology of marine coccolithophores, in: Coccolithophores, edited by: Winter, A. and Siesser, W. G., Cambridge Univ. Press, Cambridge, UK, 39-49, 1994.

Broccoli, A. J.: Tropical cooling at the Last Glacial Maximum: an atmosphere-mixed layer ocean model simulation, J Climate, 13, 951-976, 2000.

Busalacchi, A. and Picaut, J.: Seasonal variability from a model of the tropical Atlantic Ocean, J. Phys. Oceanogr., 13, 1564-1588, 1983.

Chiang, J. C., Biasutti, M., and Battisti, D. S.: Sensitivity of the Atlantic Intertropical Convergence Zone to Last Glacial Maximum boundary conditions, Paleoceanography, 18, 1094, doi:10.1029/2003PA000916, 2003.

Colmenero-Hidalgo, E., Flores, J. A., Sierro, J., Barcena, M. A., Lowemark, L., Schonfeld, J., and Grimalt, J. O.: Ocean surface water response to shortterm climate changes revealed by coccolithophores from the Gulf of Cadiz (NE Atlantic) and Alboran Sea (W Mediterranean), Palaeogeogr. Palaeocl., 205, 317-336, 2004.

Curry, W. B. and Cullen, J. L.: Carbonate production and dissolution in the western equatorial Atlantic during the last 1 M.Y.: Leg 154, in: Proc. ODP, Sci. Results, 154, edited by: Shackleton, N. J., Curry, W. B., Richter, C., and Bralower, T. J., College Station, TX (Ocean Drilling Program), 189-199, 1997.

da Silveira, I. C. A., de Miranda, L. B., and Brown, W. S.: On the origins of the North Brazil Current, J. Geophys. Res., 99, 2250122512, 1994.

de Menocal, P. B.: Plio-Pleistocene African Climate, Science, 270, 53-59, 1995.

Dittert, N., Baumann, K.-H., Bickert, R., Henrich, R., Huber, R., Kinkel, H., and Meggers, H.: Carbonate dissolution in the deepsea: methods, quantification and paleoceanographic application, in: Use of Proxies in Paleoceanography: Examples from the South Atlantic, edited by: Fischer, G. and Wefer, G., Springer Verlag, Berlin, Heidelberg, 255-284, 1999.

Ericson, D. B. and Wollin, G.: Correlation of six cores from the equatorial Atlantic and the Caribbean, Deep-Sea Res., 3, 104$125,1956$.

Ffield, A.: North Brazil current rings viewed by TRMM Microwave Imager SST and the influence of the Amazon Plume, Deep-Sea Res. I, 52, 137-160, 2005.

Fincham, M. J. and Winter, A.: Paleoceanographic interpretation of coccoliths and oxygen isotopes from sediments from the surface of Southwest Indian Ocean, Mar. Micropaleontol., 13, 325-351, 1989.

Findlay, C. S. and Giraudeau, J.: Extant calcareous nannoplankton in the Australia sector of the southern ocean (Austral summer 1994 and 1995), Mar. Micropaleontol., 40, 417-439, 2000.

Flores, J. A. and Sierro, F. J.: Revised technique for calculation of calcareous nannofossil accumulation rates, Micropaleontology, 43, 321-324, 1997.

Flores, J.-A., Gersonde, R., and Sierro, F.-J.: Pleistocene fluctuations in the Agulhas Current Retroflection based on the calcareous plankton record, Mar. Micropaleontol., 37, 1-22, 1999.

Flores, J. A., Bárcena, M. A., and Sierro, F. J.: Ocean-surface and wind dynamics in the Atlantic Ocean off Northwest Africa during the last 140,000 years, Palaeogeogr. Palaeocl., 161, 459-478, 2000.

Flores, J. A., Marino, M., Sierro, F. J., Hodell, D. A., and Charles,
C. D.: Calcareous plankton dissolution pattern and coccolithophore assemblages during the last $600 \mathrm{kyr}$ at ODP Site 1089 (Cape Basin, South Atlantic): paleoceanographic implications, Palaeogeogr. Palaeocl., 196, 409-426, 2003.

Gibbs, R. J.: Wind-controlled coastal upwelling in the western equatorial Atlantic, Deep-Sea Res., 27A, 857-866, 1980.

Gibbs, S., Shackleton, N., and Young, J.: Orbitally forced climate signals in mid-Pliocene nannofossil assemblages, Mar. Micropaleontol., 51, 9-56, 2004.

Giraudeau, J.: Distribution of Recent nannofossils beneath the Benguela system: Southwest African continental margin, Mar. Geol., 108, 219-237, 1992.

Giunta, S., Negri, A., Morigi, C., Capotondi, L., CombourieuNebout, N., Emeis, K. C., Sangiorgi, F., and Vigliotti, L.: Coccolithophorid ecostratigraphy and multi-proxy paleoceanographic reconstruction in the Southern Adriatic Sea during the last deglacial time (Core AD91-17), Palaeogeogr. Palaeocl., 190, 39-59, 2003.

Hagino, K. and Okada, H.: Floral response of coccolithophores to progressive oligotrophication in the South Equatorial Current, Pacific Ocean, in: Global Environmental Change in the Ocean and on Land, edited by: Shiyomi, M., Kawahata, H., Koizumi, H., Tsuda, A., and Awaya, Y., TERRAPUB, 121-132, 2004.

Haidar, A. T. and Thierstein, H. R.: Calcareous phytoplankton dynamics at Bermuda (N. Atlantic), EGU 9 Abstr. Suppl. 1., Terra Nova 9, p. 602, 1997.

Harris, S. and Mix, A. C.: Pleistocene precipitation balance in the Amazon Basin recorded in deep sea sediments, Quaternary Res., 51, 14-26, 1999.

Hastenrath, S. and Druyan, L.: Circulation anomaly mechanisms in the tropical Atlantic sector during the Northeast Brazil rainy season: results from the GISS General Circulation Model, J. Geophys. Res.-Atmos., 98(D8), 14017-14923, 1993.

Hastenrath, S. and Greischar, L.: Circulation mechanisms related to Northeast Brazil rainfall anomalies, J. Geophys. Res.-Atmos., 98(D5), 5093-5102, 1993.

Hastenrath, S. and Merle, J.: Annual cycle of subsurface thermal structure in the tropical Atlantic ocean, J. Phys. Res., 17, 1518$1538,1987$.

Haug, G. H., Hughen, K. A., Sigman, D. M., Peterson, L. C., and Röhl, U.: Southward migration of the Intertropical Convergence Zone through the Holocene, Science, 293, 1304-1308, 2001.

Haug, G. H., Günther, D., Peterson, L. C, Sigman, D. M., Hughen, K. A., and Aeschlimann, B.: Climate and the collapse of Maya Civilization, Science, 299, 1731-1735, 2003.

Hibberd, D. J.: The ultrastructure and taxonomy of the Chrysophyceae and Prymnesiophyceae (Haptophyceae): a survey with some new observations on the ultrastructure of the Chrysophyceae, Bot. Jo. Linn. Soc., 72, 55-80, 1976.

Hiramatsu, C. and De Deckker, P.: The late Quaternary calcareous nannoplankton assemblages from three cores from the Tasman Sea, Palaeogeogr. Palaeocl., 131, 391-412, 1997.

Hulburt, E. M. and Corwin, N.: Influence of the Amazon River outflow on the ecology of the western tropical Atlantic: III. The planktonic flora between the Amazon River and the Windward islands, J. Mar. Res., 27, 55-72, 1969.

Hüls, M. and Zahn, R.: Millennial-scale sea surface temperature variability in the western tropical North Atlantic from planktonic foraminiferal census counts, Paleoceanography, 15, 659- 
678, 2000.

Kennett, J. P. and Huddlestun, P.: Late Pleistocene Paleoclimatology, foraminiferal biostratigraphy and tephrochronology, western Gulf of Mexico, Quaternary Res., 2, 38-69, 1972.

Khodri, M., Ramstein, G., and de Noblet-Ducoudré, N.: Sensitivity of the northern extratropics hydrological cycle to the changing insolation forcing at 126 and $115 \mathrm{ky} \mathrm{BP}$, Clim. Dynam., 21, 273287, doi:10.1007/s00382-003-0333-5, 2003.

Kinkel, H., Baumann, K.-H., and Èepek, M.: Coccolithophores in the equatorial Atlantic Ocean: response to seasonal and Late Quaternary surface water variability, Mar. Micropaleontol., 39, 87-112, 2000.

Kolla, V., Biscaye, P. E., and Hanley, A. F.: Distribution of quartz in late Quaternary Atlantic sediments in relation to climate, Quaternary Res., 11, 261-277, 1979.

Lazar, A., Inui, T., Malanotte-Rizzoli, P., Busalacchi, A. J., Wang, L., and Murtugudde, R.: Seasonality of the ventilation of the tropical Atlantic thermocline in an ocean general circulation model, J. Geophys. Res., 107(C8), 3104, doi:10.1029/2000JC000667, 2002.

Lisiecki, L. E. and Raymo, M. E.: A Pliocene-Pleistocene stack of 57 globally distributed benthic $\delta^{18} \mathrm{O}$ records, Paleoceanography, 20, PA1003, doi:10.1029/2004PA001071, 2005.

Liu, Z. and Herbert, T.: High-latitude on the Eastern Equatorial Pacific climate in the early Pleistocene epoch, Nature, 427, 720723, 2004.

López-Otálvaro, G.-E., Flores, J.-A., Sierro, F.-J., and Cacho, I.: Variations in coccolithophorid production in the Eastern Equatorial Pacific at ODP Site 1240 over the last seven glacial-interglacial cycles, Mar. Micropaleontol., 69, 52-69, doi:10.1016/j.marmicro.2007.11.009, 2008.

Lynch-Stieglitz, J., Curry, W. B., and Slowey, N.: Weaker Gulf Stream in the Florida Straits during the Last Glacial Maximum, Nature, 402, 644-648, 1999.

Marino, M., Maiorano, P., and Lirer, F.: Changes in calcareous nannofossil assemblages during the MidPleistocene Revolution, Mar. Micropaleontol., 69, 70-90, doi:10.1016/j.marmicro.2007.11.010, 2008.

Marsh, M. E.: Regulation of $\mathrm{CaCO}_{3}$ formation in coccolithophores, Comp. Biochem. Physiol., 136, 743-754, 2003.

Martínez, J. I., Mora, G., and Barrows, T. T.: Paleoceanographic conditions in the western Caribbean Sea for the last $560 \mathrm{Ka}$ as inferred from planktonic foraminifera, Mar. Micropaleontol., 64, 177-188, 2007.

Masson, S. and Delecluse, P.: Influence of the Amazon river runoff on the tropical Atlantic, Phys. Chem. Earth, 26, 137-142, 2000.

Maslin, M. and Mikkelsen, N.: Amazon Fan mass transport deposits and underlying interglacial deposits: age estimates and fan dynamics: Leg 155, in: Proc. ODP, Sci. Results, 155, edited by: Flood, R. D., Piper, D. W. J., Klaus, A., and Peterson, L. C., College Station, TX (Ocean Drilling Program), 353-365, 1997.

McIntyre, A. and Bé, A. W. H.: Modern Coccolithophoridae of the Atlantic Ocean-1. Placoliths and cyrtoliths, Deep-Sea Res., 14, 561-597, 1967.

Milliman, J. D.: Production and accumulation of calcium carbonate in the ocean: budget of an unsteady state, Global Biogeochem. Сy., 7, 927-957. 1993.

Mitchell-Innes, B. A. and Winter, A.: Coccolithophores: a major phytoplankton component in mature upwelled waters off the
Cape Peninsula, South Africa in March, 1983, Mar. Biol., 95, 25-30, 1987.

Molfino, B. and McIntyre, A.: Precessional forcing of nutricline dynamics in the equatorial Atlantic, Science, 249, 766-769. 1990a.

Molfino, B. and McIntyre, A.: Nutricline variation in the equatorial Atlantic coinciding with the Younger Dryas, Paleoceanography, 5, 997-1008, 1990b.

Müller-Karger, F. E., McClain, C. R., and Richardson, P. L.: The dispersal's of the amazon water, Nature, 333, 56-59, 1988.

Müller-Karger, F. E, McClain, C. R., Fisher, T. R., Esaias, W. E., and Varela, R.: Pigment distribution in the Caribbean Sea, Prog. Oceanogr., 23, 23-64, 1989.

Müller-Karger, F. E. and Aparicio-Castro, R.: Mesoscale processes affecting phytoplancton abundance in the southern Caribbean Sea, Cont. Shelf Res., 14, 199-221, 1994.

Müller-Karger, F. E., Richardson, P. L., and McGillicuddy, D.: On the offshore dispersal of the Amazon's Plume in the North Atlantic: Comments on the paper by A. Longhurst, "Seasonal cooling and blooming in tropical oceans", Deep-Sea Res. I, 42, 2127 2137, 1995.

Okada, H.: Calcareous nannofossils from Deep Sea Drilling Project Sites 442 through 446, Philippines Sea, Initial Rep. Deep Sea, 58, 549-565, 1980.

Okada, H. and Honjo, S.: The distribution of oceanic coccolithophorids in the Pacific, Deep-Sea Res., 20, 355-374, 1973.

Okada, H. and McIntyre, A.: Modern coccolithophores of the Pacific and North Atlantic Oceans, Micropaleontology, 23, 1-55, 1977.

Okada, H. and McIntyre, A.: Seasonal distribution of modern Coccolithophores in the Western North Atlantic ocean, Mar. Biol., 54, 319-328, 1979.

Okada, H. and Wells, P.: Late Quaternary nannofossil indicators of climate change in two deep-sea cores associated with the Leeuwin Current off Western Australia, Palaeogeogr. Palaeocl., 131, 413-432, 1997.

Pailler, K., Bourlès, B., and Gouriou, Y.: The Barrier layer in the Western tropical Atlantic Ocean, Geophys. Res. Lett., 26, 2069 2072, 1999.

Peterson, L. C., Haug, G. H., Hughen, K. A., and Röhl, U.: Rapid changes in the hydrologic cycle of the Tropical Atlantic during the Last Glacial, Science, 290, 1947-1951, 2000.

Prell, W. L. and Damuth, J. E.: The climate-related diachronous disappearance of Pulleniatina obliquiloculata in Late Quaternary sediments of the Atlantic and Caribbean, Mar. Micropaleontol., 3, 267-277, 1978.

Pujos, M. and Froidefond, J.-M.: Water masses and suspended matter circulation on the French Guiana continental shelf, Cont. Shelf Res., 15, 1157-1171, 1995.

Richardson, P. L., Hufford, G., Limeburner, R., and Brown, W.: North Brazil Current retroflection eddies, J. Geophys. Res., 99, 5081-5093, 1994

Roth, P. H.: Distribution of coccoliths in ocean sediments, in: Coccolithophores, edited by: Winter, A. and Siesser, W. G., Cambridge University Press, Cambridge, 199-218, 1994.

Roth, P. H. and Berger, W. H.: Distribution and dissolution of coccoliths in the South and central Pacific, Special Publications Vol 13. Cushman Foundation for Foraminiferal Research, 87-113, 1975.

Roth, P. H. and Colbourn, W. T.: Floral and solution patterns of 
coccoliths in surface sediments of the North Pacific, Mar. Micropaleontol., 7, 1-52, 1982.

Rühlemann, C., Dickmann, B., Mulitza, S., and Frank, M.: Late Quaternary changes of western equatorial Atlantic surface circulation and Amazon lowland climate recorded in Ceara Rise deep-sea sedimentos, Paleoceanography, 16, 293-305, 2001.

Ryther, J. H., Menzel, D. W., and Corwin, N.: Influence of the Amazon River outflow on the ecology of the western tropical Atlantic: I. Hydrography and nutrient chemistry, J. Mar. Res., 25, 69-83, 1967.

Schmitz Jr., W. J.: On the interbasin-scale thermohaline circulation, Rev. Geophys., 33, 151-173, 1995.

Shipboard Scientific Party: MD132-PICASSO, IMAGES XI, Cruise Report, 76 p., 2003.

Showers, W. J. and Bevis, M.: Amazon cone isotopic stratigraphy: evidence for the source of the tropical freshwater spike, Palaeogeogr. Palaeocl., 64, 189-199, 1988.

Siesser, W. and Winter, A.: Composition and morphology of coccolithophore skeletons, in: Coccolithophores, edited by: Winter, A. and Siesser, W. G., Cambridge Univ. Press, Cambridge, UK, 51-62, 1994.

Steinmetz, J. C.: Sedimentation of coccolithophores, in: Coccolithophores, edited by: Winter, A. and Siesser, W. G., Cambridge University Press, Cambridge, 179-197, 1994.

Stramma, L., Fischer, J., and Reppin, J.: The North Brazil Undercurrent, Deep-Sea Res., 42, 773-795, 1995.

Stramma, L. and Schott, F.: Western equatorial circulation and interhemispheric exchange, in: The Warm water sphere of the North Atlantic Ocean, edited by: Krauss, W., Gebrüder Borntraeger, Berlin, Stuttgart, 195-227, 1996.

Stramma, L., Rhein, M., Brandt, P., Dengler, M., Böning, C., and Walter, M.: Upper ocean circulation in the western tropical Atlantic in boreal fall 2000, Deep-Sea Res. I, 52, 221-240, 2005.

$\mathrm{Su}, \mathrm{X}$.: Development of late tertiary and quaternary coccolith assemblages in the Northeast Atlantic, GEOMAR-Report 48, 1120, 1996.

Thierstein, H. R., Geitzenauer, K., Molfino, B., and Shackleton, N. J.: Global synchroneity of late Quaternary coccolith datum levels: validation by oxygen isotopes, Geology, 5, 400-404, 1977.

Vink, A., Zonneveld, K. A. F., and Willems, H.: Distributions of calcareous dinoflagellate cysts in surface sediments of the western equatorial Atlantic Ocean, and their potential use in paleoceanography, Mar. Micropaleontol., 38, 149-180, 2000.

Vink, A., Rühlemann, C., Zonneveld, K., Mulitza, S., Hüls, M., and Willems, H.: Shifts in the position of North Equatorial current and rapid productivity changes in the western Tropical Atlantic during the last glacial, Paleoceanography 16, 1-12, 2001.
Vink, A., Brune, C. H., Zonnevveld, K. A. F., and Willems, H.: On the response of calcareous dinoflagellates to oligotrophy and stratification of the upper water column in the equatorial Atlantic Ocean, Palaeogeogr. Palaeocl., 178, 53-76, 2002.

Wells, P. and Okada, H.: Response of nannoplankton to major changes in sea-surface temperature and movements of hydrological fronts over Site DSDP 594 (south Chatham Rise, southeastern New Zeland), during the last $130 \mathrm{Kyr}$, Mar. Micropaleontol., 32, 341-363, 1997.

Westbroek, P., Brown, C.W., Van Bleijswijk, J., Brownlee, C., Brummer, G. J., Conte, M., Egge, J., Fernández, E., Jordan, R., Knappertsbusch, M., Stefels, J., Veldhuis, M., Van Der Waal, P., and Young, J. R.: A model system approach to biological climate forcing. The example of Emiliania huxleyi, Global Planet. Change, 8, 27-46, 1993.

Wilson, W. D., Johns, W. E., and Garzioli, S. L.: Velocity structure of North Brazil current rings, Geophys. Res. Lett., 29, 8, 1273, doi:1029/2001GL013869, 2002.

Winter, A.: Paleoenvironmental interpretation of Quaternary coccolith assemblages from the Gulf of Aqaba (Elat), Red Sea. Revista Española de Micropaleontología, 14, 291-314, 1982.

Winter, A.: Distribution of living coccolithophores in the California Current system, southern California borderland, Mar. Micropaleontol., 9, 385-393, 1985.

Winter, A., Jordan, R. W., and Roth, P.: Biogeography of living coccolithophores in ocean waters, in: Coccolithophores, edited by: Winter, A. and Siesser, W. G., Cambridge University Press, Cambridge, 161-177, 1994.

Wolff, T., Multiza, S., Rühlemann, C., and Wefer, G.: Response of the tropical Atlantic thermocline to late Quaternary Trade wind changes, Paleoceanography, 14, 374-383, 1999.

Young, J. R.: Functions of coccoliths, in: Coccolithophores, edited by: Winter, A. and Siesser, W. G., Cambridge University Press, Cambridge, 63-82, 1994.

Ziveri, P., Thunell, R. C., and Rio, D.: Export production of coccolithophores in an upwelling region: results from San Pedro Basin, Southern California Borderlands, Mar. Micropaleontol., 24, 335-358, 1995.

Ziveri, P. and Thunell, R. C.: Coccolithophores export production in Guaymas Basin, gulf of California: response to climatic forcing, Deep-Sea Res. II, 47, 2073-2100, 2000.

Ziveri, P., Baumann, K.-H., Böeckel, B., Bollman, J., and Young, J.: Present day coccolithophore-biogeography in the Atlantic Ocean, in: Coccolithophores - From Molecular Processes to Global Impact, edited by: Thierstein, H. and Young, J., SpringerVerlag, 403-428, 2004. 